\title{
E FORAM FELIZES PARA SEMPRE (?): REFLEXÕES SOBRE CASAMENTO E (IN)FELICIDADE NAS LITERATURAS BALZAQUIANA E CAMILIANA
}

\author{
And they were happily ever after (?): \\ reflections on marriage and (un)happiness in \\ Balzacian and Camilian literature
}

\author{
Ana Luísa Patrício Campos de Oliveira*
}

\begin{abstract}
RESUMO
De fato, a felicidade é um dos maiores anseios humanos. E é também uma de suas mais profundas angústias, pois a sua conquista parece sempre um tanto quanto inalcançável ou fluida demais para ser retida por longo tempo. No século XIX, esta busca pela felicidade se processa, muitas vezes, pela via do casamento. Com efeito, muitos escritores oitocentistas procuraram retratar a proximidade destes dois temas em seus romances, entre os quais destacamos o francês Honoré de Balzac e o português Camilo Castelo Branco. No presente artigo, propomo-nos a analisar dois romances, um balzaquiano e outro camiliano, com vistas a estudarmos como a busca pela felicidade e a contração do matrimônio resultam em uma forma de crítica às sociedades francesa e portuguesa oitocentistas.

Palavras-chave: Honoré de Balzac; Camilo Castelo Branco; critica social.
\end{abstract}

\begin{abstract}
Surely, happiness is one of the greatest human aspirations. And it is one of our deepest sufferings as well, since its conquest seems to be somewhat unachievable or too fluid to be


retained for a long period. In the nineteenth century, this pursuit for happiness is processed oftentimes trough marriage. Indeed, many nineteenth-century writers seek to portray the proximity of these two themes in their novels, among which we highlight the French Honoré de Balzac and the Portuguese Camilo Castelo Branco. In this article, we propose to analyze two novels, one Balzacian and another Camilian, intending to study how the pursuit of happiness and the contraction of marriage result in a form of criticism of the nineteenth French and Portuguese societies.

Keywords: Honoré de Balzac; Camilo Castelo Branco; social criticism.

De fato, a felicidade é um dos maiores anseios humanos. E é também uma de suas mais profundas angústias, pois a sua conquista parece sempre um tanto quanto inalcançável ou fluida demais para ser retida por longo tempo. No século XIX, esta busca pela felicidade se processa, muitas vezes, pela via do casamento, questão muito presente na literatura romanesca do período: "Os leitores e os estudiosos da ficção do século XIX sabem que ela girou fundamentalmente ao redor do tema do casamento, tendo como eixo central a figura feminina." (ORIONE, 2010, p. 296).

Isso porque o romance oitocentista constitui-se enquanto um gênero dedicado à descrição e à análise do cotidiano da burguesia, classe social em franca ascensão econômica e principal consumidora/leitora dos exemplares ficcionais publicados na época: é digna de nota "a novidade do romance oitocentista, que, pela primeira vez, tratou seriamente a realidade cotidiana das classes sociais inferiores, sobretudo a da pequena burguesia, enquadrando os dramas vividos pelas personagens dentro de uma perspectiva histórica em constante mutação." (ORIONE, 2010, p. 296). Assim sendo, encontramos, neste período, exemplares romanescos que, tendo em vista o público leitor burguês, buscam ser um "relato autêntico das experiências reais dos indivíduos" (VASCONCELOS, 2002, p. 14) e "levanta[m] de forma aguda o problema da correspondência entre a obra literária e a realidade que ela imita." (VASCONCELOS, 2002, p. 13) ${ }^{1}$.

Com efeito, muitos escritores oitocentistas procuraram retratar a proximidade destes dois temas, a felicidade e o casamento, em seus romances, entre os quais destacamos o francês Honoré de Balzac e o português Camilo

1 Dada a brevidade do presente estudo, não será possível tecermos comentários mais aprofundados acerca das especificidades da ascensão do romance e de suas particularidades em França e Portugal, bem como de todos os valores que permeiam as sociedades burguesas francesa e portuguesa oitocentistas. Aqui pretendemos apenas apontar a importância das temáticas do casamento e da busca pela felicidade junto ao romance oitocentista, a fim de mostrarmos como Honoré de Balzac e Camilo Castelo Branco valem-se destas questões tão caras ao século XIX ao compor seus romances La femme de trente ans e A Queda d'um anjo. 
Castelo Branco - autores frequentemente abordados de forma comparatista pela crítica especializada ${ }^{2}$, justamente devido à preocupação partilhada por ambos de descrever e analisar as sociedades que os cercam:

A designação de "Balzac português", aplicada a Camilo é legítima, se por ela entendemos que o autor das Novelas do Minho ocupa, em Portugal, a posição de Balzac em França - a do primeiro romancista que abordou a vida de seu tempo, procurando pintar a sociedade a que pertencia. (CASTRO, 1960, p. 123-124)

No presente estudo, analisaremos duas obras, a balzaquiana $L a$ femme de trente ans (1842) e a camiliana $A$ Queda d'um anjo (1865), romances que enfocam de maneira central os mencionados temas, de modo a tornar possível a veiculação de suas críticas às sociedades francesa e portuguesa oitocentistas. Passemos às análises.

Em La femme de trente ans, romance balzaquiano emblemático ${ }^{3}$, é-nos narrada a trajetória de Julie de Chatillonest, uma jovem francesa que, em 1813, no auge de sua adolescência, enamora-se perdidamente, durante uma apresentação militar napoleônica na Praça do Carrousel, pelo coronel Victor d'Aiglemont, dada a sua beleza, força e altivez no comando de seu cavalo:

Quando terminaram as manobras, o oficial galopou e parou diante do imperador para esperar ordens. Nesse momento, estava a vinte passos de Júlia, diante do grupo imperial [...]. A rapariga pode então

2 Vale ressaltar que, apesar de Balzac e Camilo serem constantemente aproximados comparativamente pela crítica literária portuguesa (Cf. BRAGA, s/d, COELHO, 2001, CORDEIRO, 1869), desde a contemporaneidade dos autores até os dias atuais existe apenas um volume crítico que analisa a obra dos romancistas mais detidamente. Trata-se do volume intitulado Balzac em Portugal (1960), do crítico Aníbal Pinto de Castro.

3 Segundo Paulo Ronai, “A Mulher de Trinta Anos é, sem contestação, o livro mais famoso de Balzac. Muitos leitores não lhe conhecem senão este único romance. Pessoas que não lhe leram uma página sequer associam automaticamente esse título a seu nome. No Brasil como em muitos outros países a 'idade balzaquiana' tornou-se expressão consagrada até nos meios incultos, e outro dia vimos 'Seu Balzac' e a mulher de trinta nos aparecerem juntos na letra de um samba." (RONAI, 1954, p. 507). Contudo, apesar de ser uma obra balzaquiana muito conhecida, justamente por trazer como tema central os dilemas de uma mulher madura, analisando o seu papel "na sociedade e, em particular, dentro do casamento" (RONAI, 1954, p. 509-510), ela é considera pela crítica como um romance falho, pois seria composta por uma junção de "contos separados" (RONAI, 1954, p. 508), cujo único traço comum seria "o fato de terem por protagonista uma mulher desiludida" (RONAI, 1954, p. 508). Muito embora não partilhemos deste mesmo ponto de vista crítico, uma vez que este romance balzaquiano traz em seu cerne uma abordagem aprofundada, coerente e verossímil de questões pertinentes à sociedade francesa oitocentista retratada - como a busca da felicidade versus o caráter indissolúvel de um casamento católico, assim como procuraremos demonstrar neste artigo -, este exemplar balzaquiano não possui muitos estudos a seu respeito, a não ser em breves notas introdutórias, como esta que acabamos de citar de Paulo Ronai. Por este motivo, não traremos avultadas contribuições críticas acerca deste exemplar ficcional ao longo do presente artigo. 
admirar o enamorado em todo o seu esplendor militar. O coronel Vitor d'Aiglemont, com trinta anos de idade, pouco mais ou menos, era alto, elegante, esbelto; e suas felizes proporções destacavam-se melhor quando empregava toda a força em governar o cavalo, cujo dorso elegante e flexível parecia vergar ao seu peso. O rosto másculo e moreno possuía este encanto inexplicável que uma perfeita regularidade de traços comunica às fisionomias jovens. [...] Seu aspecto, desses que a bravura assinalou, oferecia o tipo que hoje o artista procura quando pensa simbolizar um dos heróis da França imperial. [...] (BALZAC, 1954, p. 520-521)

Encantada, Julie não atende às súplicas de seu pai, que afirma não residir nesse enlace e futuro casamento a felicidade de sua filha, uma vez que Victor, apesar de belo, vigoroso e altivo, possui um caráter egoísta, esbanjador e embrutecido pelos anos de serviço militar. Por meio de um diálogo entre pai e filha, é possível percebermos o quanto o pai consegue prever o futuro infeliz de Julie:

- Pois bem! Minha filha, escuta-me. As moças criam frequentemente nobres, arrebatadoras imagens, figuras ideais, e forjam ideias quiméricas a respeito dos homens, dos sentimentos, do mundo; depois atribuem inocentemente a um caráter as perfeições que sonharam e nisso confiam; amam no homem de sua escolha essa criatura imaginária; porém mais tarde, quando não há mais tempo para libertar-se da infelicidade, a ilusória aparência que embelezaram, seu primeiro ídolo enfim se transforma num esqueleto odioso. Júlia, eu preferia saber-te apaixonada por um velho a ver-te enamorada do coronel. [...] Conheço Vítor; sua alegria é uma alegria sem espírito, de caserna, ele não tem talento e é gastador. É um desses homens que o céu criou para tomar e digerir quatro refeições por dia, dormir, amar a primeira que apareça e bater-se. [...] Parou por um momento, contemplando a filha, e acrescentou: -Mas, minha pobre Júlia, é ainda muito moça, muito frágil, muito delicada para suportares os pesares e lida do casamento. D'Aiglemont foi mimado pelos parentes, assim como o foste por sua mãe e por mim. Como esperar que ambos possam entender-se com vontades diferentes cujas tiranias serão inconciliáveis? Serás vítima ou tirana. Ambas as alternativas trazem soma igual de infelicidade à vida de uma mulher. Mas és meiga e modesta, serás a primeira a submeter-se. Enfim tens, - disse em voz alterada - uma graça de sentimento que será desconhecida, e então...

Não terminou, as lágrimas venceram-no. (DE BALZAC, 1954, p. 523)

Sem levar em conta os conselhos de seu pai, Julie se torna a Sra. d'Aiglemont. No entanto, assim como previra seu velho progenitor, ela não 
encontra a felicidade no casamento e perde o viço e a alegria de viver, dada a rudeza de seu marido militar. De fato, em pouco menos de um ano de casada, "Júlia d'Aiglemont já não parecia mais com a moça que outrora corria com alegria e felicidade à parada das Tulherias. Seu rosto, sempre delicado, não mais possuía as cores rosadas que antigamente lhe davam um brilho tão rico." (DE BALZAC, 1954, p. 526).

Estava infeliz. Sente-se violentada pelo marido e não vê diferença entre a sua condição de esposa que não mais ama seu cônjuge e a de uma prostituta. Mas Julie, ao tornar-se mãe, consegue reconciliar-se um pouco com sua vida, pois a maternidade lhe permite afastar-se de seus deveres conjugais por algum tempo. Contudo, este sopro de felicidade não dura muito. Temendo que seu afastamento possa gerar um desinteresse permanente em seu marido, Julie decide "reconquistar seu império" (DE BALZAC, 1954, p. 549) sobre Victor, que a esta altura da narrativa já é marquês. Com efeito, Julie toma esta atitude, pois acredita que, se outra mulher conquistar o amor de seu marido, quem sofrerá as consequências será sua Hélène:

[...] Nesse momento ela não pensou mais em si, nem nos seus sofrimentos nem nos seus sacrifícios. Foi apenas mãe, e encarou a fortuna, o futuro, a felicidade da filha; sua filha, a única criatura que lhe proporcionava um pouco de felicidade; sua Helena, o único bem que lhe prendia à vida. Agora, Júlia desejava viver para preservar a filha do jugo medonho sob o qual uma madrasta poderia sufocar a vida daquele ente querido. (DE BALZAC, 1954, p. 547-548)

Dessa forma, embora padecesse em demasia, Julie decide abrir mão, definitivamente, de sua felicidade em nome da de sua filha. Entretanto, um evento marcante faz com que a infelicidade da protagonista atinja um nível quase insuportável para ela. É quando o Lord Arthur Grenville, homem gentil e galante pelo qual Julie nutre um amor profundo e contemplativo, morre para que ninguém saiba que ele havia tido um encontro noturno com sua amada: "Um homem adorado, jovem e generoso, a cujos desejos jamais acedera, a fim de obedecer às leis da sociedade, tinha morrido para lhe preservar aquilo a que a sociedade chama a honra de uma mulher." (DE BALZAC, 1954, p. 573-574, grifo do autor).

Depressiva e vivendo à base de medicamentos, Julie começa a vislumbrar em Hélène a personificação de todos os seus sofrimentos e não consegue mais entrever na maternidade uma fonte de afeto e felicidade. Em um dado momento, valendo-se de um tom marcadamente grave, ela desabafa com um padre que vem a sua casa tentar lhe confortar: 
- [...] Sou mãe apenas pela metade, e antes não o fosse em nada. Helena não é dele [Arthur]. [...] Tenho uma filha, mais nada; sou mãe, assim o quer a lei. [...] A pobrezinha da minha Helena é filha de seu pai, é filha do dever e do acaso; em mim só encontra o instinto da fêmea, a lei que nos impele irresistivelmente a proteger a criatura nascida de nós. Socialmente falando, sou irrepreensível. Já não sacrifiquei a ela minha vida e minha felicidade? Seus gritos movem a minha sensibilidade; se ela caísse n'água, eu me atiraria para salvá-la. Mas não a tenho no coração. [...] (DE BALZAC, 1954, 580-581)

Mais adiante, Julie fala de forma ainda mais contundente ao padre sobre seus sentimentos por Hélène e como sua falta de amor não será nem mesmo motivo de censura social se ela souber como manter as aparências:

- Eis o âmago de meu coração. [...] Para mim o dia é cheio de trevas, o pensamento um gládio, meu coração é uma chaga, minha filha é uma negação. Sim, quando Helena me fala, queria ouvir-lhe uma outra voz; quando me fita, queria que tivesse outros olhos. Ela está aí para me atestar tudo o que deveria ser e tudo o que não é. Ela me é insuportável. Sorrio-lhe, tento compensá-la dos sentimentos que lhe roubo. Sofro! oh! senhor, sofro demasiado para poder viver. E passarei por ser uma mulher virtuosa! E não cometi faltas! E respeitar-me-ão! (DE BALZAC, 1954, p. 581-582)

Nesse sentido, Julie passa a amargar sua infelicidade e sua ausência de amor maternal sem conseguir se resignar ou se refugiar, por exemplo, na religião. Segundo ela, não há espaço para a crença religiosa em uma vida oprimida pela sociedade: "[...] As leis sociais pesam-me demasiado sobre o coração e mo dilaceram muito fortemente para que eu possa elevar-me ao céu. Mas as leis sociais talvez não sejam tão cruéis como os costumes da sociedade. Oh! A sociedade!" (DE BALZAC, 1954, p. 579). E o padre afirma que ela "só tornará a Deus quando sentir o peso de sua mão" (DE BALZAC, 1954 , p. 584).

Finalmente, aos trinta anos, momento da trajetória da protagonista que dá nome ao romance, ela sai de seu estado meditativo e decide voltar a viver. Muito mais experiente, ela cede à sedução ${ }^{4}$ de um segundo amante,

4 Vale mencionar que Julie não cede às seduções de Charles simplesmente por ter chegado aos trinta anos, ser mais experiente e ter mais controle sobre seus sentimentos e atitudes. Como bem afirma Paulo Ronai, [...] se ela cede às insistências de Carlos de Vandenesse, não é por haver chegado a essa idade [trinta anos], mas sim por haver sofrido muito em consequência de um casamento inadequado e, sobretudo, do desastre puramente fortuito em que perdeu o homem que amava [Arthur] de uma paixão ideal. (RONAI, 1954, p. 509). É importante destacar ainda que, de acordo com o crítico, o 
Charles de Vandenesse, mas de modo que a sociedade não perceba. A este respeito, afirma o narrador:

[...] Somente aos trinta anos uma mulher pode conhecer os recursos dessa situação. À custa dela ri, brinca, se enternece sem se comprometer. Possui então o tato necessário para atacar no homem todas as cordas sensíveis, e para estudar os sons que delas tira. $\mathrm{O}$ seu silêncio é tão perigoso quanto as suas palavras. Nunca se pode adivinhar se, nessa idade, ela é sincera ou falsa, se zomba ou se está de boa fé nas suas confissões. [...] (DE BALZAC, 1954, p. 594)

Como fruto desse enlace, Julie concebe um filho, Charles, pelo qual consegue nutrir todo o amor que julgava ser capaz. Contudo, assim como profetizara o padre com o qual conversara naquela ocasião, a mão de Deus não tarda a pesar sobre aqueles que não se voltam a ele. Em um capítulo denominado "O dedo de Deus", Hélène, acidentalmente, mata seu irmão mais novo, alvo de um ciúme constante por este ser mais amado pela mãe do que ela. Vejamos como o narrador descreve esta cena lançando mão de um tom acentuadamente grave:

Vendo o irmão no declive do talude, Helena lançou-lhe o mais horrível olhar que jamais iluminou os olhos duma criança, e empurrou-o com um movimento de raiva. Carlos escorregou pela encosta íngreme, indo de encontro a raízes que o atiraram violentamente sobre as pedras cortantes do muro; partiu a cabeça, e depois, sangrando, foi cair nas águas barrentas do rio. A superfície líquida abriu-se em mil gotas escuras sob a linda cabecinha loura. [...] Helena, estupefata, soltava gritos pungentes:

- Mamãe! Mamãe!

A mãe achava-se ali [...]. Voara como o vento. Mas nem os olhos da mãe nem os meus [narrador] podiam encontrar o lugar preciso em que a criança estava sepultada. A água negra borbulhava num espaço imenso. Nesse local, o leito do Briève tem dez pés de lodo. O menino fatalmente morreria; era impossível socorrê-lo. Àquela hora, num domingo, tudo estava em repouso. [...]

Helena tinha talvez vingado o pai. Seu ciúme era sem dúvida o gládio de Deus. [...] (DE BALZAC, 1954, p. 608-609)

mérito deste romance balzaquiano reside justamente no fato de ele ter curado "o amor do preconceito da mocidade" (RONAI, 1954, p. 511), valorizando a maturidade feminina: "Balzac prestou às mulheres um serviço imenso, que elas nunca lhe poderão agradecer suficientemente, pois duplicou a idade do amor. Antes dele, todas as namoradas de romance tinham vinte anos. Ele prolongou até aos trinta, até os quarenta anos a sua vida ativa, pleiteando, em seu favor, a causa da natureza, da verdade. [...] Multiplicou senão a alegria humana, pelo menos a consciência desta alegria" (RONAI, 1954, p. 511). 
Com efeito, esse acidente dramático finda por transmitir, conotativamente, a mensagem de que a sociedade, com a anuência da providência divina, jamais permitirá que Julie seja feliz enquanto ela trilhar um caminho não aceito pelas leis sociais e por Deus, mais especificamente o catolicismo. Segundo o narrador, trata-se de mais um episódio de infelicidade extrema na vida da protagonista: "Um tal acontecimento devia causar um abalo medonho na vida duma mulher, e eis um dos ecos mais terríveis que de tempos em tempos perturbavam a vida afetiva de Júlia." (DE BALZAC, 1954, p. 609).

Depois desse golpe, os anos se passam, Julie continua casada, amante de Charles de Vandenesse e tem mais três filhos, Gustave, Abel e Moïna. Após sofrer mais alguns baques da vida, entre eles a fuga de Hélène com um assassino e a perda da fortuna de seu marido, que parte para reconquistá-la na América e morre de "esgotamento de fadiga" (DE BALZAC, 1954, p. 652) ao atingir seu objetivo, Julie envelhece e vai morar com Moïna, sua filha mais amada e a de personalidade mais difícil.

Contudo, seu sofrimento nunca cessa. No capítulo final intitulado "A velhice duma mãe culpada", Julie sofre por ver sua Moïna trilhar o mesmo caminho de perdição que ela percorreu: sua filha é casada, infeliz em seu casamento e amante do filho de Charles de Vandenesse, Alfred de Vandenesse, seu meio-irmão. Julie padece e se culpa ainda mais, pois, uma vez que seu caso com Charles nunca fora descoberto, Alfred tem livre acesso à casa de Moïna, proximidade esta que, talvez, tenha engendrado toda a desgraça que acomete em silêncio à vida de sua filha querida:

[...] A Sra. d'Aiglemont, a quem uma longa experiência ensinara a conhecer a vida, a julgar os homens, a temer a sociedade, observava os progressos desse namoro e pressentia a perda da filha vendo-a cair nas mãos dum homem para quem nada era sagrado. Não havia para ela qualquer coisa de espantoso em encontrar um sedutor no homem a quem Moína escutava com prazer? Sua filha querida estava à beira de um abismo. [...] Embora Alfredo de Vandenesse causasse horror àquela infeliz mãe, ela estava obrigada a sepultar no âmago do coração as razões supremas de sua aversão. Ela estava intimamente ligada ao Marquês de Vandenesse, pai de Alfredo, e essa amizade, respeitável aos olhos da sociedade, autorizava o rapaz a frequentar familiarmente a casa da Sra. de Saint-Héreen, pela qual simulava uma paixão concebida desde a infância. [...] (DE BALZAC, 1954, p. 661, grifo do autor)

Por fim, Julie acaba morrendo de desgosto quando Moïna, friamente, a acusa de haver tido um relacionamento com Charles, um golpe derradeiro que seu coração cansado não suporta. Esta cena decorre no momento em que a mãe tenta aconselhar a filha a não se relacionar com Alfred: 
- Minha mãe, - exclamou Moína com um ar arrogante e interrompendo-a, - eu sei o que a senhora vem me dizer... Vem me censurar por causa de Alfredo...

- Tu não adivinharias tão bem [...].

$[\ldots]$

- Mamãe, pensei que só tivesses ciúmes do pai [Charles de Vandenesse]...

A essa frase, a Sra. d'Aiglemont fechou os olhos, baixou a cabeça e soltou o mais leve de todos os suspiros. Voltou os olhos para o alto, como que obedecendo ao sentimento invencível que nos faz invocar Deus nas grandes crises da vida, e depois dirigiu à filha um olhar cheio de terrível majestade, no qual transparecia também uma dor profunda.

- Minha filha - disse ela numa voz intensamente alterada - foste mais impiedosa para com tua mãe do que o homem que ela ofendeu, mais do que o será Deus, talvez.

A Sra. d'Aiglemont ergueu-se; mas ao chegar à porta, voltou-se, viu apenas surpresa nos olhos da filha, saiu, e conseguiu ir até o jardim, onde suas forças a abandonaram. Lá, sentindo fortes dores no coração, caiu sobre um banco. [...]

- Não assuste minha filha! - foram as últimas palavras que pronunciou aquela mãe.

[...] Nesse momento supremo ela conheceu a mãe, e não podia mais nada reparar. [O último] [...] sorriso [da mãe] provava àquela jovem matricida que o coração duma mãe é um abismo em cujo fundo se encontra sempre um perdão. (DE BALZAC, 1954, p. 664-665)

Depois de observarmos a trajetória conturbada de Julie, descrita em todos os seus pormenores dramáticos por meio de um tom enunciativo grave, podemos perceber que a personagem sempre busca sua felicidade de diversas formas, mas nunca consegue desfrutá-la de forma duradoura, nem no casamento, nem na maternidade e tampouco no adultério, pois ela é sempre atormentada pela culpa, seja por ter se arrependido de casar voluntariamente com um homem bruto e se tornado, segundo ela, uma prostituta sob a tutela da sociedade e com as bênçãos de Deus, seja por ter cedido às seduções de Charles de Vandenesse ou por não ter sido uma mãe amorosa e dedicada para todos os seus filhos. Vale ressaltar que a providência divina possui um papel marcante nesta ação narrativa e também na culpa sentida pela personagem, visto que, toda vez que Julie burla as leis sociais ou às de Deus, da Igreja Católica, para ir em busca de sua felicidade, algo terrível ocorre $^{5}$, como a morte de seu filho Charles por sua filha Hélène, para lhe lembrar de não mais ceder às falácias de seu desejo.

5 No que concerne a este aspecto cristão que cerceia a vida das personagens balzaquianas, Balzac, em seu "Avant-Propos" à Comédie Humaine, afirma ser este um "elemento de ordem social", ou seja, algo que, de fato, existe em sua obra para conter "as tendências depravadas do homem". 
Em síntese, temos em La femme de trente ans uma narrativa que mostra a infelicidade de uma mulher casada, presa social e religiosamente a um homem que não ama e cuja situação de infelicidade é inescapável, pois, ainda que ela tente ser feliz, como ela o faz sempre em desacordo com seu casamento, ou seja, em desacordo com a sociedade francesa que a cerca e contrariando às leis de Deus, ao catolicismo, Julie está, incontornavelmente, fadada à infelicidade advinda de uma trajetória de vida marcada por desgraças.

Assim posto, passemos, nesse momento, à apreciação de um romance camiliano que, como veremos, em muito difere da obra balzaquiana que acabamos de analisar no que tange à abordagem grave dos temas do casamento e da busca pela felicidade. Em $A$ Queda d'um anjo, encontramos descrita a trajetória do protagonista Calisto Elói de Silos e Benevides de Barbuda, uma personagem extremamente apegada às tradições clássicas e a questões de linhagem:

Calisto Elói de Silos e Benevides de Barbuda, morgado da Agra de Freimas, tem hoje quarenta e nove anos, por ter nascido em 1815, na aldeia de Caçarelhos, termo de Miranda.

Seu pai, também Calisto, era cavaleiro fidalgo com filhamento, e décimo sexto varão dos Barbudas da Agra. Sua mãe, D. Basilissa Escolástica, procedia dos Silos, altas dignidades da Igreja, comendatários, sangue limpo, já bom sangue no tempo do Sr. rei D. Afonso I, fundador de Miranda.

Fez seus estudos de latinidade no seminário bracarense o filho único do morgado da Agra de Freimas, destinando-se a doutoramento in utroque jure. Porém, como quer que o pai lhe falecesse, e a mãe contrariasse a projectada formatura, em razão de ficar sozinha no solar de Caçarelhos, Calisto, como bom filho, renunciou à carreira das letras, deu-se ao governo do casal algum tanto, e muito à leitura de copiosa livraria, parte de seus avós paternos, e a maior dos doutores em cânones, cónegos, desembargadores do eclesiástico, catedráticos, chantres, arcediagos e bispos, parentela ilustríssima de sua mãe.

\footnotetext{
Vejamos o excerto completo: "O homem não é bom, nem é mau; nasce com instintos e aptidões; a sociedade, longe de depravá-lo, como afirma Rousseau, o aperfeiçoa, torna-o melhor; mas o interesse também desenvolve suas más tendências. o cristianismo, e sobretudo o catolicismo, sendo como eu o disse no Médico Rural, um sistema completo de repressão das tendências depravadas do homem, é o maior elemento de ordem social." (DE BALZAC, 1993, p. 671). Contudo, afirma Paulo Ronai que Balzac, neste romance, procura mostrar muito mais as imperfeições da sociedade francesa oitocentista do que o quanto a religião pode castigar e civilizar o homem, ainda que o aspecto religioso sempre venha à baila, pois o romancista é "partidário do trono e do altar": "As teorias verdadeiramente revolucionárias que o livro encerra acerca do destino da mulher na sociedade e, em particular, dentro do casamento, são expostas não pelo autor, mas pela Sra. de Aiglemont. Sente-se, pela veemência do tom, que o romancista, nesse pormenor, partilha as teorias da personagem; mas quando passa a falar em seu próprio nome, lembrando-se de que é um partidário do trono e do altar, atribui à falta de religiosidade da protagonista desgraças que, segundo ele próprio o demonstra, decorrem da imperfeição das instituições." (RONAI, 1954, p. 509-510).
} 
Casou o morgado, ao tocar pelos vinte anos, com sua segunda prima D. Teodora Barbuda de Figueiroa, morgada de Travanca, senhora de raro aviso, muito apontada em amanho de casa, ignorante mais que o necessário para ter juízo.

Unidos os dois morgadios, ficou sendo a casa de Calisto a maior da comarca; e, com o rodar de dez anos, prosperou a olho, tendo grande parte neste incremento a parcimónia a que o morgado circunscreveu seus prazeres, e, por sobre isto, o génio cainho e apertado de D. Teodora. (CASTELO BRANCO, 1986, p. 839-840)

Casado convenientemente com sua prima Teodora Barbuda de Figueiroa, Calisto vive de forma pacata, gastando suas horas, seus dias, sua existência lendo todo tipo de obra antiga, cultuando a História, o passado, a moral e a religião católica e rechaçando o progresso que, segundo ele, traz a corrupção em seu bojo:

Os livros de Calisto Elói eram cronicões, histórias eclesiásticas, biografias de varões preclaros, corografias, legislação antiga, forais, memórias da Academia Real da História Portuguesa, catálogos de reis, numismática, genealogias, anais, poemas de cunho velho, etc. [...]

Calisto Elói de Silos e Benevides de Barbuda queria que se venerasse o passado, a moral antiga como o monumento antigo, as leis de João das Regras e Martim de Ocem, como o mosteiro da Batalha, as Ordenações Manuelinas como o convento dos Jerónimos.

$[\ldots]$

Em suma, Calisto era legitimista quieto, calado, e incapaz de empecer a roda do progresso, contanto que o progresso não lhe entrasse em casa, nem o quisesse levar consigo. (CASTELO BRANCO, 1986, p. 840-841)

Além desse culto às tradições e ao passado, Calisto Elói também se preocupa com a corrupção que assola Portugal, pois o país está se modernizando, esquecendo-se de seus costumes. Em um dado momento, Calisto decide falar publicamente sobre suas convicções:

[...] o morgado, convicto da podridão dos vereadores em particular, e da humanidade em geral, prometeu a onze retratos, que tinha de onze avós, pintados indignamente, nunca mais tocar o cancro social com suas mãos impolutas.

$[\ldots]$

Um dia, porém, quando ele saía da festividade de S. Sebastião, cujo mordomo era, deteve-se no adro, onde o rodearam os mais graúdos lavradores da sua freguesia e das vizinhas. 
$[\ldots]$

Obrigado às orelhas do auditório atento, Calisto, em toada de Ezequiel, continuou:

- Portugal está alagado pela onda da corrupção, que subverteu a Roma imperial! Os costumes de nossos maiores são metidos a riso! As leis antigas, que eram o baluarte das antigas virtudes, dizem os sicofantas modernos que já não servem à humanidade, a qual, em consequência de ter mais sete séculos, se emancipou da tutela das leis. (Alusão ervada aos vereadores de Miranda, que discreparam do intento restaurador do foral dado por D. Afonso. Vinham a ser sicofantas os colegas municipalenses.) Credite, posteri! - exclamou Calisto Elói com ênfase, nobilitando a postura. (CASTELO BRANCO, 1986, p. 844-845)

Logo depois deste discurso público bradado contra a corrupção na política, Calisto é eleito deputado e parte para Lisboa em busca da regeneração dos costumes portugueses. Vale dizer que sua partida traz muita tristeza para os esposos, que pela primeira vez viverão apartados um do outro:

De propósito, saltamos por cima dos pormenores da partida, para não descrever o quadro lastimoso do apartamento de Calisto e Teodora.

O apartamento de Teodora e Calisto era título para dois capítulos de lágrimas. (CASTELO BRANCO, 1986, p. 844-845)

Com efeito, até esse momento da narrativa não se fala em felicidade, tema não abordado nem pelas personagens nem pelo narrador. Assim sendo, podemos inferir que o casamento morno de conveniências vivido por Calisto e Teodora não é fonte de felicidade nem de infelicidade, talvez por nenhum dos dois haverem tido outros amores ou sonhos de felicidade amorosa. Contudo, esta realidade mudará em pouco tempo, uma vez que Calisto Elói começará a se preocupar com tal questão. Vejamos como isto decorre.

De fato, Calisto chega à capital portuguesa imbuído da tentativa de contribuir para a recuperação de um "Portugal moribundo" (CASTELO BRANCO, 1986, p. 862), fazendo discursos embasados em suas leituras clássicas e nos costumes mais tradicionais do Portugal velho. Discursos repletos de anacronismos que "Faz[em] rir o Parlamento" (CASTELO BRANCO, 1986, p. 870 ), conforme intitula um capítulo do romance. No entanto, como afirma Maria Isabel Rocheta, apesar do ridículo das suas

referências, das suas maneiras, do seu vestuário[,] [n]o Parlamento, $[. .$.$] Calisto revela o lado positivo da sua rigidez de espírito na$ 
inteireza com que sustenta os seus valores, combatendo o partido governamentalista. Defende o povo contra o excesso dos impostos; advoga o bom uso dos dinheiros públicos [...]. A par da justiça e do saneamento das finanças, defende a língua portuguesa, criticando a retórica florida com que a generalidade dos deputados [...] se deleita [...]. (ROCHETA, 2002, p. 525, grifo do autor).

Dessa forma, mesmo com seu comportamento anacrônico, Calisto Elói "ganha [...] consideração na Câmara e no País" (CASTELO BRANCO, 1986, p. 881). Entretanto, como prenuncia o título da obra, Calisto, até então um "homem-anjo" (CASTELO BRANCO, 1986, p. 885), cuja "pureza de vida" (CASTELO BRANCO, 1986, p. 885) já contava "quarenta e quatro anos imaculados" (CASTELO BRANCO, 1986, p. 885), sofre uma transformação. Isto porque o morgado apaixona-se por Adelaide Sarmento e por ela sente, pela primeira vez, seu coração bater mais forte. Acerca desta paixão, comenta, jocosamente, o narrador camiliano:

Eis que, a súbitas, do coração de Calisto ressalta a primeira faísca de amor!

Conheço que este desastre não se devia contar sem grandes prólogos. Sei que o leitor ficou passado com esta notícia. Grita que a inverosimilhança é flagrante. Não pode de boamente consentir que se lhe desfigure a sisuda fisionomia moral do marido de D. Teodora Figueiroa. Quer que se limpe da fronte deste homem o estigma de um pensamento adúltero. Honrados desejos!

$[\ldots]$

Foi neste instante que o morgado da Agra de Freimas sentiu no lado esquerdo do peito, entre a quarta e a quinta costela, um calor de ventosa, acompanhado de vibrações eléctricas, e vaporações cálidas, que lhe passaram à espinha dorsal, e daqui ao cérebro, e pouco depois a toda a cabeça, purpureando-lhe as maçãs de ambas as faces com o rubor mais virginal. (CASTELO BRANCO, 1986, p. 901-902)

Por conta de seu amor por Adelaide, em um capítulo intitulado "Vai cair o anjo!”, Calisto Elói dá início ao seu processo de modernização. Como primeira medida progressista, o morgado troca toda a sua vestimenta aldeã por trajes mais elegantes e modernos, fato que o faz rejuvenescer aos olhos de todos, principalmente aos de sua amada:

[...] Disse ela à mana Catarina que a fronte de Calisto parecia alumiada, e no todo das feições e ademanes se revelava certa nobreza e garbo, que o faziam parecer mais novo. 
E era assim. Os quarenta e quatro anos do morgado, vividos na aldeia, e no resguardo da biblioteca, viçavam ainda frescura de mocidade. A reforma do trajar fora grande parte nisto. A casaca antiga, e o restante da roupa trazida de Miranda tolhiam-lhe a elegância das posturas e movimentos, nos primeiros discursos. (CASTELO BRANCO, 1986, p. 923)

No entanto, ainda não é desta vez que Calisto terá sua paixão correspondida. Adelaide, apaixonada por Vasco da Cunha, fica sabendo que o morgado da Agra de Freimas é casado e, a pedido do pai, retira-se de bom grado com sua irmã Catarina para uma quinta em Campolide. Cônscio da rejeição de sua amada e ainda muito "intransigente na defesa do povo e do bom-senso" (ROCHETA, 2002, p. 525), Calisto tem "horas de insônia" (CASTELO BRANCO, 1986, p. 926) pensando em sua mulher Teodora e nos votos de "fidelidade que deve a mulher ao marido, essa mesma [que] deve $o$ marido à mulher" (CASTELO BRANCO, 1986, p. 926). Pensamentos cristãos que, em verdade, Calisto Elói não consegue sustentar por muito mais tempo em Lisboa.

Certo dia, uma prima do morgado, Ifigênia de Teive Ponce de Leão, viúva do tenente-coronel Gonçalo Teles Teive Ponce de Leão, faz-lhe uma visita e, uma vez que Calisto Elói não está em casa, deixa-lhe um bilhete de visita em sua escrivaninha. No momento em que o morgado chega a sua casa e lê o nome escrito no bilhete,

Desfilaram por diante do espírito de Calisto Elói regimentos de ilustres famílias oriundas dos Teles e dos Teives e dos Ponces de Leão. $\mathrm{Na}$ linhagem dos Barbudas também alguma vez tinham entrado os Teives, e uma décima nona avó de Calisto viera de Espanha, e era Ponce, dos Ponces genuínos dos duques de Banhos. (CASTELO BRANCO, 1986, p. 940).

Encantado com as brilhantes linhagens que lhe figuram na mente, D. Tomásia, vizinha de Calisto que havia visto Ifigênia, faz a seguinte descrição sedutora acerca da jovem viúva:

- Eu só sei dizer - respondeu D. Tomásia - que é uma criatura linda, linda quanto se pode ser!

- Como assim?! - atalhou Calisto, retendo uma lasca de presunto entre os dentes molares - pois ela não é a viúva de um tenente-general, que naturalmente havia de morrer velho?

- Pode ser que ele morresse velho; mas a viúva o mais que pode ter é trinta anos. 
- E com que então, galante?

- É uma imagem de cera. V. Ex ${ }^{a}$ há-de vê-la. E tão elegante! A cintura cabe aqui - prosseguiu D. Tomásia, formando um anel com dois dedos. - Eu, quando ouvi parar uma carruagem, cuidei que era $\mathrm{V}$. Ex ${ }^{\mathrm{a}}$ e vim abrir as portas do escritório. A senhora veio subindo, e puxou à campainha. Eu espreitei lá de cima, e, a falar a verdade, lembrei-me se seria a sua esposa, que lhe quisesse fazer uma agradável surpresa. Perguntou-me ela pelo Sr. Barbuda de Benevides, e foi entrando comigo para a sala. Levantou o véu, e disse: "Não está em casa?" Que voz, Sr. morgado, que voz de criatura aquela! (CASTELO BRANCO, 1986, p. 940)

"Calisto, digamo-lo sem refolhos, caiu." (CASTELO BRANCO, 1986, p. 938) Em outras palavras, Calisto, mesmo antes de conhecer pessoalmente sua linda prima de linhagens ainda mais belas, já estava completamente apaixonado. Apaixonado por Ifigênia e entediado das "sinceras baboseiras" (CASTELO BRANCO, 1986, p. 946) que Teodora lhe escreve em cartas, Calisto Elói passa a mentir para a sua esposa, afirmando precisar de mais dinheiro para negócios e tranquilizando-a com frases repletas de carinho e juras de fidelidade e afeto sincero:

Prima Teodora e estimada esposa.

Passo bem de saúde; mas saudoso de ti. Não te tenho escrito, porque os negócios do Estado me levam todo o tempo. Mandei vir dinheiro de Bragança, para empresas de grande vantagem. Não te dê cuidado os meus gastos, que somos muito ricos, e não temos filhos. Até aqui vivemos miseravelmente; quando eu voltar a casa, quero que mudes de vida, prima. Hei-de reformar o nosso palacete de Miranda, e viveremos como nossos avós, com representação e comodidades próprias deste tempo. É preciso gozarmos a vida, que é curta. Não andes por lá a medir grão nem a tratar das aves. Entrega isso às criadas, e faze-te a senhora e fidalga que és.

[...] Lembra-te que és uma Figueiroa, casada com um Barbuda. Se receberes ordem minha, em mão de algum negociante de Bragança, paga o dinheiro que disser a ordem.

Não te lembres de infidelidades do teu Calisto. [...] Quando vier o recoveiro de Miranda, manda-me presunto, salpicões, e algumas ancoretas do vinho da Ribeira.

Teu muito afecto e extremoso

Calisto. (CASTELO BRANCO, 1986, p. 946-947)

Em pouco tempo, Calisto e Ifigênia se tornam amantes e ele somente se lembra de sua esposa quando o dinheiro começa a lhe faltar. Por sua vez, Teodora começa a desconfiar da total ausência de seu marido e manda Brás 
Lobato a Lisboa saber o que está ocorrendo com seu primo e ele retorna da capital com a seguinte notícia: "- Seu marido está perdido, Sra. Morgada." (CASTELO BRANCO, 1986, p. 970).

Inconformada com o abandono, Teodora intenciona ir ao encontro dele em Lisboa, mas esta viagem não chega a ser concluída, pois Calisto Elói decide ir ao encontro de sua esposa a fim de evitar maiores transtornos. Contudo, ao chegar a sua quinta, Calisto se "enoja" (CASTELO BRANCO, 1986, p. 980), sente "horror" (CASTELO BRANCO, 1986, p. 980) tanto da "choradeira" (CASTELO BRANCO, 1986, p. 980) de Teodora quanto de tudo que a cerca, principalmente do provincianismo que reina naquele lugar. Ao cabo do "suplício de alguns dias" (CASTELO BRANCO, 1986, p. 982), Calisto já não consegue olhar sua mulher sem que "uma enchente de ódio, e logo desprezo" (CASTELO BRANCO, 1986, p. 982) o consuma. Sem mais ser capaz de permanecer ao lado de Teodora, o morgado decide ir embora e, mesmo estando sua esposa doente - ela "ardia em febre" (CASTELO BRANCO, 1986, p. 983) dado o nervoso de toda aquela situação -, Calisto "não se comove" (CASTELO BRANCO, 1986, p. 984) e parte para Lisboa "alegre como o encarcerado da prisão de longos anos. As asas cândidas de Ifigênia sacudiam-lhe do espírito saudades e remorsos." (CASTELO BRANCO, 1986, p. 984).

Depois desse episódio, é a vez de Teodora sofrer algumas modificações e também partir em busca de sua felicidade. Após ir a Lisboa constatar a traição de seu marido, que se retirara para França a fim de evitar um escândalo ainda maior, Teodora "afoga [...] em lágrimas as últimas e mais entranhadas raízes de sua pureza” (CASTELO BRANCO, 1986, p. 993). Abdicando de seus valores cristãos, Teodora adapta-se às contingências às quais foi exposta: ela muda suas vestimentas, passa a se portar enquanto uma mulher de posses e aceita se tornar amante de seu primo Lopo. Assim sendo, encontramos um paralelismo evidente entre as trajetórias de Teodora e Calisto Elói, pois ambos encontram a felicidade no adultério com seus primos, vivem ricos, tornam-se barões e ainda têm filhos que intencionam legitimar tão logo um dos dois morra. A este respeito, afirma jocosa e satiricamente o enunciador camiliano:

o barão esperava que a mulher morresse, para legitimar os seus meninos [...].

A baronesa, que, digamo-lo depressa, não rejeitou o título do marido, esperava que o marido se aniquilasse na perdição dos seus costumes, para também legitimar o seu Bernabé. [...] O amor é tão engenhoso como a natureza.

Deixá-lo ser feliz: deixá-lo. Calisto Elói, aquele santo homem lá das serras, o anjo do fragmento paradisíaco do Portugal velho, caiu.

Caiu o anjo, e ficou simplesmente o homem, homem como quase todos os outros, e com mais algumas vantagens que o comum dos homens. 


\begin{abstract}
Dinheiro a rodo!
Uma prima que o preza muito!

Dois meninos que lhe cavalgam no costado!

Saúde de ferro!

E barão!

Conjectura muita gente que ele é desgraçado, apesar da prima, do baronato, dos meninos, do dinheiro e da saúde.

Eu, como já disse, não sei realmente se lá no recesso daqueles arcanos domésticos há borrascas.

Na qualidade de anjo, Calisto, sem dúvida, seria mais feliz; mas, na qualidade de homem a que o reduziram as paixões, lá se vai consertando menos mal com a sua vida. (CASTELO BRANCO, 1986, p. 1004-1005)
\end{abstract}

Antes de finalizarmos a análise desse romance, vale evidenciar que Calisto Elói também se adapta à corrupção política do Parlamento de Lisboa aderindo ao partido governamental. Ele afirma aos que se indignam com sua nova opção: "- Estou português do século XIX." (CASTELO BRANCO, 1986, p. 989). Acerca desta adaptação de Calisto Elói à corrupta sociedade portuguesa oitocentista, afirma João Camilo dos Santos:

[...] O herói não conseguiu modificar o mundo nem regenerar os costumes; o 'anjo' provinciano acabou mesmo por 'cair', como indica o título do romance, deixando-se assimilar pelo demônio da Civilização. Por outras palavras: Calisto integrou-se e fê-lo rapidamente. O homem, finalmente, é o que o meio social em que vive faz dele. (SANTOS, 1992, p. 51)

Dessa forma, Calisto Elói encontra sua felicidade no adultério e na corrupção dos costumes, assim como Teodora "viv[e] [...] contente, esquecida, feliz [...]" (CASTELO BRANCO, 1986, 1001) sendo adúltera, fidalga, mãe e baronesa.

Como podemos perceber, diferentemente do que ocorre em La femme de trente ans, nesse romance camiliano as amarras sociais se soltam facilmente e a felicidade não encontrada no casamento pode ser conquistada permanentemente no adultério sem que a providência divina castigue aqueles que não mais seguem as leis de Deus e da Igreja Católica. Neste tocante, o narrador camiliano faz o seguinte comentário derradeiro:

$\mathrm{Eu}$, como romancista, lamento que ele não viva muitíssimo apoquentado, para poder tirar a limpo a sã moralidade deste conto. 
Fica sendo, portanto, esta coisa uma novela que não há-de levar ao Céu número de almas mais vantajoso que o do ano passado. (CASTELO BRANCO, 1986, p. 1005)

Em outros termos, o enunciador assegura jocosamente que "a felicidade infernal do crime" (CASTELO BRANCO, 1986, p. 1000) não é punida nesta obra camiliana e o narrador não pode, a partir dos fatos narrados, "tirar a limpo a sã moralidade deste conto" (CASTELO BRANCO, 1986, p. 1005), ou seja, todos podem ser felizes a partir de suas escolhas, de acordo ou não com as leis sociais e a sociedade portuguesa que, corrupta como é, acaba por absorver mais um "crime" (CASTELO BRANCO, 1986, p. 1000) sem que ninguém se sinta culpado ou que a providência intervenha no destino das personagens que optam por transgredir os preceitos sociais e cristãos.

Assim sendo, podemos observar que ambas as obras possuem como temas centrais o casamento e a busca da felicidade, bem como o modo como estes motes se articulam às sociedades francesa e portuguesa oitocentistas e também às leis da Igreja Católica. Como vimos, em La femme de trente ans, temos uma narrativa enunciada em tom grave acerca de uma protagonista fadada à infelicidade por conta de seu casamento, uma "prostituição legal" (DE BALZAC, 1954, p. 579) regulamentada pela sociedade e indissolúvel segundo os preceitos cristãos. Tendo sofrido golpes atrozes da vida, como a morte seu filho Charles por sua outra filha Hélène, por conta de um ciúme fraternal que Julie mesmo engendrou, a personagem balzaquiana é um exemplo de mulher, esposa, mãe e amante culpada e sempre castigada pela providência divina quando busca sua felicidade fora dos regras sociais e católicas, pois, ainda que ela consiga enganar a sociedade para tentar ser feliz, ela nunca consegue escapar dos castigos de Deus.

Muito distante dessa visão inescapável do casamento infeliz, encontramos a visão camiliana jocosa e satírica presente em $A$ Queda d'um anjo. De fato, Calisto Elói e Teodora encontram a felicidade no adultério sem que nada nem ninguém os incomode, ou seja, diferentemente do que vimos no romance balzaquiano, a sociedade e a providência divina não interferem em seus destinos: eles encontram o amor junto aos seus primos, têm filhos, seus prestígios sociais aumentam - tornam-se barões - e suas fortunas não acabam. Em outras palavras, quando a felicidade não se apresenta no enlace matrimonial, as personagens apresentadas por Camilo têm a possibilidade de buscá-la e desfrutá-la da forma que bem lhes aprouver, com a anuência social, sem a interferência de Deus e, principalmente, sem nenhuma "punição" (OLIVEIRA, 2010, p. 121).

A esse respeito, o crítico Paulo Motta Oliveira afirma que a sociedade portuguesa capitalista apresentada pelo autor português constitui-se 
enquanto um ambiente no qual a moralidade possui pouca importância e no qual o que realmente tem valor é o dinheiro e os arranjos que são estabelecidos pelas personagens entre seus desejos e o capital que possuem para subsidiá-los:

[...] a moralidade é, na ficção camiliana, uma quimera, e o papel preponderante que o desejo e, mais que este, o dinheiro, nelas [obras camilianas] possui. Assim, é natural que o autor [Camilo] várias vezes chegue a afirmar que a literatura não tem, nem pode vir a ter, nenhum poder pedagógico. (OLIVEIRA, 2010, p. 127)

Assim posto, apesar das diversas visões sobre o que as personagens podem fazer a partir de seus casamentos infelizes e dos tons dessemelhantes empregados pelos narradores dos romances em tela para descrever o desenrolar desses matrimônios - o tom grave balzaquiano versus o tom jocoso e satírico camiliano -, a verdade é que ambas as obras literárias mostram a quase total incompatibilidade entre o casamento e a concretização da felicidade no século XIX. Incompatíveis, resta à personagem balzaquiana casada e infeliz a culpa e o sofrimento que a encaminham a uma morte amarga e dolorosa; já às personagens camilianas existe um caminho alternativo, muitas possibilidades ainda estão disponíveis e suas escolhas são o adultério feliz, a maternidade/paternidade e uma vida abastada no luxo e na riqueza. Visões de mundo que demostram o quanto as mundividências balzaquiana e camiliana presentes nos romances em foco diferem, apesar de preocupadas com as mesmas questões, as eternas demandas humanas da união e da felicidade.

\section{REFERÊNCIAS}

BRAGA, Teófilo. História da Literatura Portuguesa VI, As Modernas Ideias na Literatura Portuguesa, O Ultra-romantismo. Lisboa: Publicações Europa-América, s/d.

CASTELO BRANCO, Camilo. A Queda d'um anjo. In: Obras Completas / Camilo Castelo Branco. Porto: Lello \&Irmãos, 1986, v. 2.

CASTRO, Aníbal Pinto de. Balzac em Portugal. Coimbra: Coimbra Editora, 1960.

COELHO, Jacinto do Prado. Introdução ao estudo da novela camiliana. Lisboa: Imprensa Nacional Casa da Moeda, 2001.

CORDEIRO, Luciano. Livro de Crítica: arte e literatura portuguesa d'hoje, 1868-1869. Porto: Tipografia Lusitana, 1869.

DE BALZAC, Honoré. A mulher de trinta anos. In: A Comédia Humana. Rio de Janeiro: Editora Globo, 1954, vol. 3. 
OLIVEIRA, A. L. P. C. DE. E forAm FElizes PARA SEMPRE (?): REFleXões SOBRE CASAMENTo...

Prefácio à Comédia Humana. In: A Comédia Humana. Rio de Janeiro: Editora Globo, 1993, vol. 17, p. 659-678.

OLIVEIRA, Paulo Motta. Camilo: limites do desejo no mundo do capital. In: Leituras do Desejo em Camilo Castelo Branco. Guimarães: Opera Omnia, 2010. p. 115-130.

ORIONE, Eduino José. A desestabilização da poética realista em Alves \& Cia.. In: ALVES, C. C., PAVANELO, L. M., SOUZA, R. S. M., OLIVEIRA, A. L. P. C. de, Repensando a Literatura Portuguesa Oitocentista: ensaios críticos. São Paulo: Editora 24x7, 2010. p. 295-321.

ROCHETA, Maria Isabel. (A) Queda d'um anjo. In: FERRAZ, Maria de Lourdes A. (Org). Dicionário de personagens da novela camiliana. Lisboa: Editorial Caminho, 2002. p. 523-529.

RONAI, Paulo. Nota Introdutória. In: A Comédia Humana. Rio de Janeiro: Editora Globo, 1954, vol. 3, p. 507-511.

SANTOS, João Camilo dos. Os malefícios da literatura, do amor e da civilização: ensaios sobre Camilo Castelo Branco. Lisboa: Fim de Século, 1992.

VASCONCELOS, Sandra. Dez liçóes sobre o romance inglês do século XVIII. São Paulo: Boitempo, 2002.

Submetido em: 31/03/2013

Aceito em: 13/12/2013 